\title{
Research on Developing Logistics Service Quality Evaluation Index System under Internet of Things Environment
}

\author{
T. Li \& X.Q. Hu \\ Harbin University of Commerce, Harbin, China
}

J.L. Pu

Harbin Institute of Technology, Harbin, China

$\mathrm{H} . \mathrm{Xu}$

Heilongjiang University, Harbin, China

\begin{abstract}
Internet of Things (IoT) Technology has been widely used in modern logistics service, with which logistics service's quality was improved and service range was extended. This paper is aimed at developing a new logistics service quality evaluation index system which takes application of IoT technology into concern. The new evaluation index system is implemented with 3 dimensions: enterprise service quality, customer perceived quality and special quality, along with 8 primary indices and 24 secondary indices. It may be useful for both logistics enterprise and IoT technology enterprise.
\end{abstract}

KEYWORD: logistics service quality; evaluation index system; internet of things

\section{INTRODUCTION}

At present, Technology of the Internet of things (IoT) plays an important role in the logistics process, such as transportation, storage, and distribution process (Andreas Nettsträter 2010). The impact of IoT on logistics activities cannot be ignored, and naturally become the factors to be considered in the study of logistics service quality. But now the evaluation index system of logistics service quality constructs no or little account of IoT technology influence.

In study of logistics service quality evaluation index system, Perrault and Russ (Perrault \& Russ 1974) firstly developing 7Rs theory based on time and space utility for evaluating logistics service quality, which including goods correct rate, goods intact rate, accurate product information, on time delivery rate, delivery accuracy rate, time and price. The famous Finland scholar Gronroos (Gronroos 1982) proposed customer perceived service quality model based on the theory of cognitive psychology, in which service quality is divided into "technology quality" and "function quality" two categories, the former refers to the output of service process, the latter refers to how customers get the service, at the same time, also points out some marketing factors affecting the service quality. 7Rs theory does not take into account the level of customer perceived service quality, customer perceived service quality model and the Kano model study logistics service quality from the customer perspective, but lack of enterprises' factors. So the two main theory both have disadvantages.

This paper study of logistics service quality, not only concern of customer satisfaction, but also consider the enterprise's provided service, at the same time, take the station change bring by IoT technology into the logistics service into consideration, so as to complete the logistics service quality evaluation index system. The logistics under IoT environment is first described in section 2 , and then logistics service quality evaluation index under IoT environment is addressed in section 3 and 4.

\section{LOGISTICS UNDER IOT ENVIRONMENT}

The development and wide application of IoT technology make it played a positive role in logistics, as shown in figure 1 . Such as simplify the logistics activities, reduce inventory level, strengthen the safety protection measures, convenient for demand forecasting, realize goods tracking and positioning, and update goods information.

\section{SELECTION PROCESS OF LOGISTICS SERVICE QUALITY EVALUATION INDEX UNDER IOT ENVIRONMENT}

Based on previous research, considering the enterprise's factors and the application of IoT technology, logistics service quality is divided into 3 
dimensions that contains enterprise service quality, customer perceived quality and special quality,

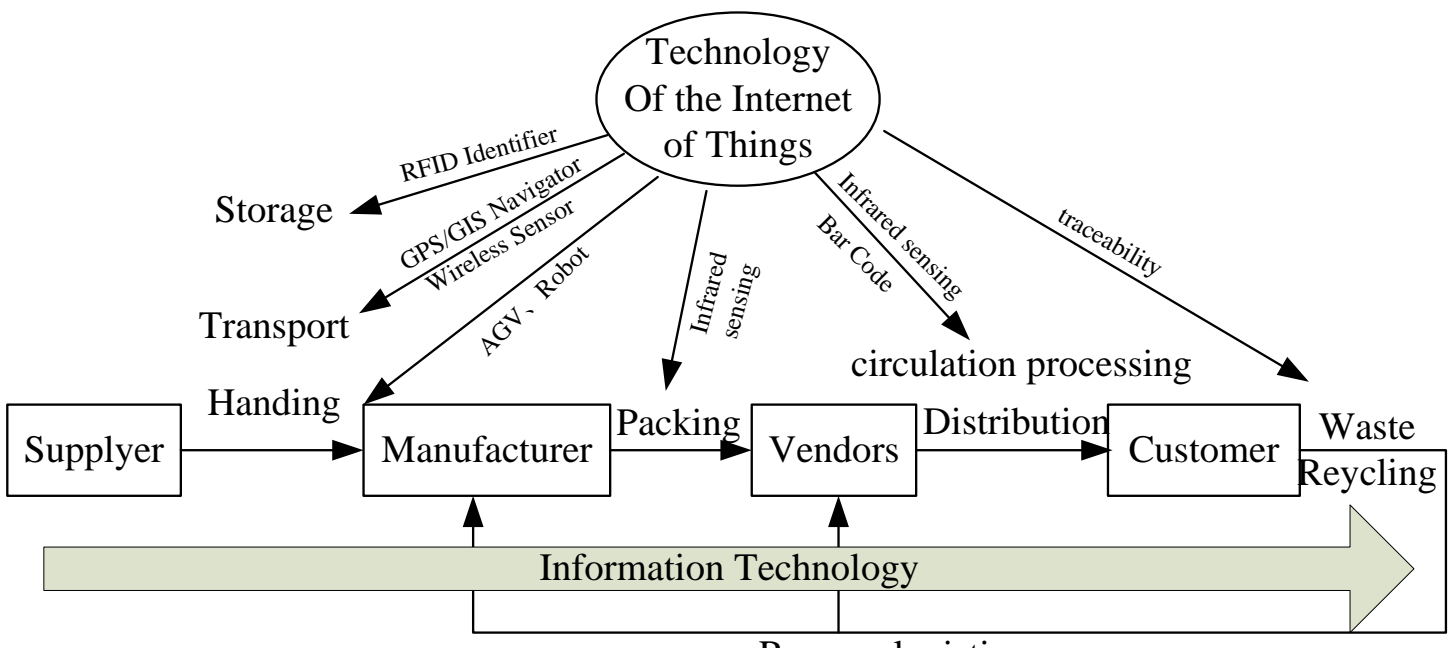

Reverse logistics

Figure 1. Using of IoT technology in logistics service

\subsection{Enterprise Service Quality}

Enterprises service quality refers to enterprise provided service for customer according to its own conditions. This dimension is standing on the enterprise point of view, focus on technology, time (speed) and goods three aspects, which evolved from Mentzer's 9 dimensions logistics service quality evaluation index system (Mentzer 2001). Specific indicators are as follows:

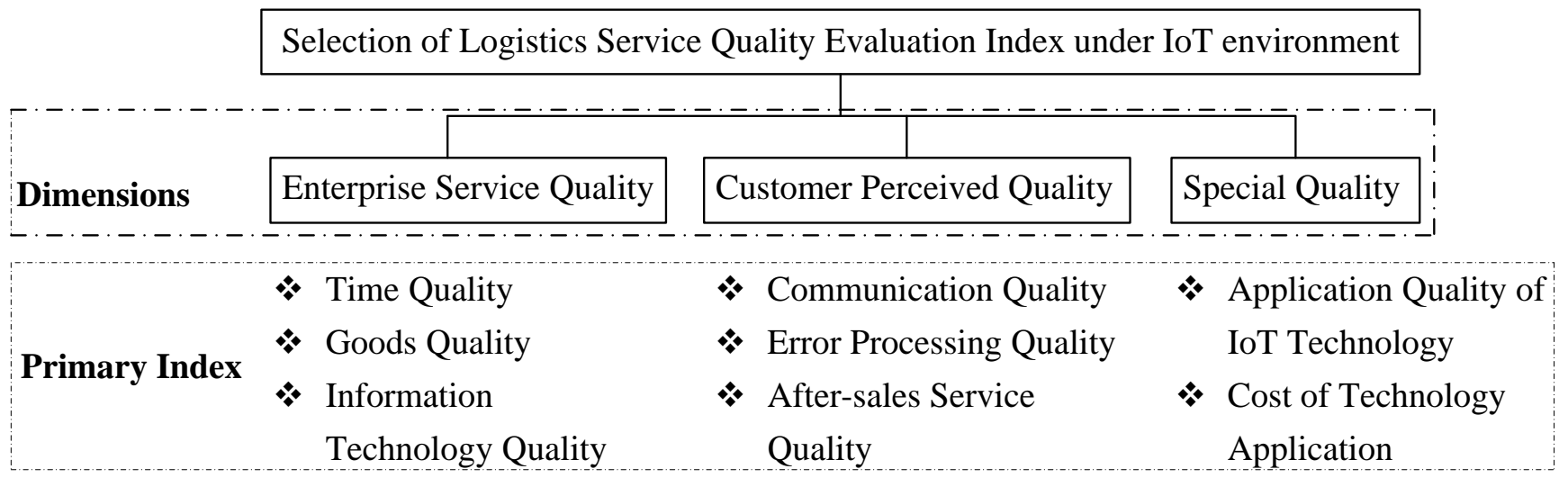

Figure 2. Selection of logistics service quality evaluation index under IoT environment

(1) On time delivery rate: Enterprises deliver the goods to customers within specified time.

(2) Efficiency: required time in some work, it's not only the staff work ability evaluation index, but also reflect the logistics service quality index.

(3) Quick responsiveness ability: Enterprises ability to solve customers' temporary other service requirements.

(4) Goods intact rate: The degree of goods protection in the process of transportation and the goods integrity after delivered to the customer.

(5) Packaging quality: Packaging condition.

(6) Demand forecast accuracy: The accuracy degree of forecast value consistent with the actual demand.
(7) Technology and equipment update capacity: Application of advanced technology and its update speed.

(8) Information system coverage: The application degree and range of IoT technologies.

(9) Information sharing: The degree of information sharing, including information sharing between enterprise and enterprise, between enterprise and customer, and within enterprise.

(10) Goods tracking quality: positioning and tracking of goods position is high quality service enterprise provides for the customer by the application of IoT technology.

(11) Online service quality: Logistics service quality evaluation index under information network environment. (Hao 2014) 


\subsection{Customer Perceived Quality}

Customer perceived quality from the view of customer perspective to measure the level of logistics service quality, by which customers perception and expectation of logistics service for the enterprises, including the communication quality, error processing quality, and after-sales service quality. The communication quality and error processing quality combines 9 dimensions logistics service quality evaluation index proposed by Mentzer (Mentzer 2001). Specific indicators are as follows:

(12) Staff service attitude: The staff remained in service attitude, occupation accomplishment and polite. Staff service attitude is representative of enterprise culture and image, and is direct form of customer perceived service, is the key factor to influence the customer evaluation of logistics service quality.

(13) Individual requirements: Staff understand customer demand for personalized services, bring more space for enterprises, improve the logistics service quality.

(14) Emergency handling ability: Emergency handing ability represents whether the enterprise can still provide customer service under special circumstances agility.

(15) Customer relationship maintenance quality: While enterprise provides service for customer, the work of maintaining customer relationships and training of customer loyalty.

(16) Processing quality of different goods: When there are differences of quality, quantity, time, place or other aspects, between enterprise provided goods and customers required goods, how to carry on the service recovery, as well as subsequent processing work.

(17) Handling quality of customer's own error: The ability of solving problem that enterprise provides logistics service failed to meet customer expectations because of customer's own mistakes.

(18) Success rate of handling the complaints: Proportion of enterprise staff successfully processed customer complaints to the overall cases of customer complaints.

(19) Processing quality of back or adjusted goods: The staff attitude and treatment measures when enterprise meeting customer's back or adjust goods requirement, for which some reason or problems (including two aspects of enterprise and customer).

\subsection{Special Quality}

The special quality proposed in this paper from both the customer and the enterprise view, because of the application of IoT technology in logistics bring different effects of enterprise and customer. It includes application quality of IoT technology and cost of technology application. Specific indicators are as follows:

(20) Technology rationality: On the one hand, refers to the enterprise carried out comprehensive analysis on the IoT technology application, including convenience and the cost. On the other hand, refers to if the IoT technology could satisfy the customer's demand for services.

(21) Technological innovation: It can be concerned both from the perspective of the enterprise and the customer. For the enterprise, whether the application of IoT technology breakthrough in the service and management. For the customers, after the enterprises' application of IoT technology, whether it bring customers new experiences and feelings.

(22) Cost of buying: In order to improve service quality and management level, the cost spent enterprise needed to purchase for introducing IoT technology.

(23) Cost of using: The cost when enterprise using IoT technology. Such as maintenance, system upgrades, and other expenses.

(24) Cost of appreciation: Appreciation costs are proposed on the customer point of view, because of using IoT technology, enterprise's cost and charge will be added to the cost of logistics service, the enterprise service fee will also be increased.

\section{LOGISTICS SERVICE QUALITY EVALUATION INDEX SYSTEM UNDER IOT ENVIRONMENT}

Basing above analysis, this paper will to construct the logistics service quality evaluation index system under IoT environment as shown in table 1. From a macro perspective, this is the inevitable trend of rapid development in socio-economic and technologic, previous logistics service quality evaluation index system has not fully applied in general today. From the microscopic point of view, building of logistics service quality based on application of IoT technology to provide a reliable basis for enterprise on their own logistics service quality evaluation, as well as a measure for the customer to the enterprise logistics service quality, and provide strong support to choice and decisionmaking.

\section{CONCLUSIONS}

This study has addressed the logistics service quality evaluation index system under IoT environment. The proposed index system fully concern the application of IoT technology in logistics service, based on previous research, considering enterprise's factor, 
customer's factor, and IoT technology factor, the whole index is divided into 3 dimensions: enterprise service quality, customer perceived quality and special quality, along with 8 primary indicts: Time Quality, Goods Quality, Information Technology Quality, Communication Quality, Error processing quality, After-sales service quality, Application Quality of IoT Technology, Cost of Technology Application, and 24 secondary indicts. This index system is suitable for enterprise carry on their own logistics service quality evaluation, and provide a develop focus for IoT technology's application.

Table 1. Logistics service quality evaluation index system under IoT environment.

\begin{tabular}{|c|c|c|}
\hline Dimensions & primary index & Secondary Index \\
\hline \multirow{11}{*}{$\begin{array}{l}\text { Enterprise Service } \\
\text { Quality }\end{array}$} & \multirow{3}{*}{ Time Quality } & On time Delivery Rate \\
\hline & & Efficiency \\
\hline & & Quick Responsiveness Ability \\
\hline & \multirow{3}{*}{ Goods Quality } & Goods Intact Rate \\
\hline & & Packaging Quality \\
\hline & & Demand Forecast Accuracy \\
\hline & \multirow{5}{*}{ Information Technology Quality } & Technology and Equipment Update Capacity \\
\hline & & Information System Coverage \\
\hline & & Information Sharing \\
\hline & & Goods Tracking Quality \\
\hline & & Online Service Quality \\
\hline \multirow{8}{*}{$\begin{array}{l}\text { Customer Perceived } \\
\text { Quality }\end{array}$} & \multirow{4}{*}{ Communication Quality } & Staff Service Attitude \\
\hline & & Individual Requirements \\
\hline & & Emergency Handling Ability \\
\hline & & Customer Relationship Maintenance Quality \\
\hline & \multirow{2}{*}{ Error Processing Quality } & Processing Quality of Different Goods \\
\hline & & Handling Quality of Customer's Own Error \\
\hline & \multirow{2}{*}{ After-sales Service Quality } & Success Rate of Handling the Complaints \\
\hline & & Processing Quality of Back or Adjusted Goods \\
\hline \multirow{5}{*}{ Special Quality } & \multirow{2}{*}{$\begin{array}{l}\text { Application Quality of IoT } \\
\text { Technology }\end{array}$} & Technology Rationality \\
\hline & & Technological Innovation \\
\hline & \multirow{3}{*}{ Cost of Technology Application } & Cost of Buying \\
\hline & & Cost of Using \\
\hline & & Cost of Appreciation \\
\hline
\end{tabular}

\section{ACKNOWEDGEMENT}

This work was financially supported by the humanities and social science research project of department of education in Hei Longjiang province (1254b005), Scientific Research Fund for Doctor of Harbin University of Commerce(13DW012).

\section{REFERENCES}

[1] Andreas Nettsträter, Jan R. Nopper, Christian Prasse, Michael ten Hompel. 2010. The Internet of Things in Logistics. 06:15-16.
[2] Hao Chang. 2014. Service quality model building for third party logistics enterprise under the Information network environment based on LSQ model. System Information Engineering. 01:63-63.

[3] Gronroos, C. 1982. An applied service marketing theory. European Journal of Marketing, 16(7): 30-41.

[4] Mentzer, John T. Daniel J and G. Tomas, M. Hult. 2001. Logistics service quality as a Segment-Customized process. Journal of Marketing. 82-101.

[5] Perrault. William D, Frederick Russ. 1974. Physical distribution service: A neglected aspect of marketing management. MSU Business Topics. 22(2):37-45. 